\title{
IMAN DAN AMAL SALEH DALAM ALQURAN (STUDI KAJIAN SEMANTIK)
}

\author{
Dindin Moh Saepudin, M.Solahudin, Izzah Faizah Siti Rusydati Khairani \\ Fakultas Ushuluddin UIN Sunan Gunung Djati Bandung \\ Jl.A.H.Nasution 105 Cibiru Bandung 40614, Indonesia \\ E-Mail :din25181@gmail.com
}

\begin{abstract}
Abstrak
Iman dan amal saleh, suatu term penting dalam Alquran, karena iman dan amal salalu disebutkan, terkadang iman dan amal saleh bersandingan, yang tentunya mengisyaratkan pesan penting untuk diteliti. Tujuan dari penelitian ini ialah untuk mengetahui bagaimana iman dan amal saleh dalam Alquran dengan pendekatan semantik T.Izutsu.Metode yang digunakan ialah deskriptif-analisis, yaitu mengambarkan secara umum mengenai objek serta menganalisis dengan jenis penelitian kepustakaan (library research).Hasil penelitian ini menunjukan iman dan amal saleh dalam Alquran menunjukan saling berkaitan antara satu dengan yang lainnya, jika amal saleh disebutkan tanpa iman maka tidak akan berguna, walaupun perbuatannya baik, tidak akan mendapatkan sesuatu. Sebaliknya, jika perbuatan itu kecil tetapi dengan iman maka akan mendapatkan pahala. Selain itu, term amal saleh dalam Alquran menunjukan makna yang luas baik kepada Allah, manusia, dan makhluk-Nya.
\end{abstract}

Kata Kunci :

Amal Saleh; Iman;makna; Semantik.

\begin{abstract}
:
Iman and amal saleh (faith and good deed) are two important terms in the Qur'an that always stated together to support one another. Both term firmly wedded in the Qur'an should indicate someimportant meaning to be explored. This article attempts to investigate the meaning of iman and amal shaleh in the Qur'an using semantics analysis offered by Toshihiko Izutsu. This study employs qualitative methods on library research and analized descriptively. This research shows that iman and amal shaleh in the Qur'an connected to one another semantically. When the term amal shaleh stands alone, and without iman, it is useless because no matter good one deed will get no rewards. On the contrary, when one do good thing although a little, one will received reward (pahala). Besides, the term amal shaleh in the Qur'an covers a wide range of meaning related to God, human and other God's creatures.
\end{abstract}

Keywords:

Amal Saleh; Iman; Semantics; meaning.

\section{A. PENDAHULUAN}

Pendekatan semantik dalam penafsiran kontemporer menjadi hal baru terhadap pengungkapan makna-makna Alquran. Kajian utama penafsiran kontemporer ialah kata-kata tertentu (key words) yang dianggap penting dalam konsep Islam ataupun permasalahanpermasalahan baru yang diperlukan jawaban secara cepat dan komprehensif. Salah satu kelebihan penggunaan semantik untuk mengungkap maksud ayat Alquran ialah dapat memahami makna ditinjau dari penggunaan bahasa tersebut, berdasarkan waktu dan penggunaan bahasa. Terlebih lagi mengonsentrasikan pada kata-kata tertentu secara komprehensif, serta mampu menemukan hubungan makna kata yang satu dengan yang lainnya.

Salah satu kata kunci Islam dalam Alquran ialah iman dan amal saleh, karena iman dan amal saleh selalu disebutkan dalam Alquran baik secara terpisah maupun beriringan. Tentunya ada kehususan dan keistimewaan bagaimana iman dan amal saleh di dalam Alquran, apakah sama seperti pemhaman Ulama bahwa iman itu percaya 
kepada Allah dan Rasulnya, sedangkan amal saleh ialah menjalankan perintah Allah dan menjauhi larangannya ataukah lebih dari itu, maka perlu dikaji dengan semantik untuk mengetahui bagaimana Iman dan amal saleh secara komperhanship.

\section{B. METODE PENELITIAN}

Kajian semantik merupakan suatu pendekatan untuk mengetahui makna pada simbol bahasa tertentu secara leksikal dan struktural. Semantik digunakan sebagai bagian dari kajian linguistik untuk mengetahui suatu makna bahasa. ${ }^{1}$

Salah satu tokoh yang memperkenalkan semantik Alquran ialah Toshiko Izutsu dengan teori semantik Alquran. Dia merupakan pengagas teori semantik pada Alquran. Sebelumnya para peneliti Alquran di Barat belum pernah menggunakan teori Semantik pada Alquran. Hal ini senada dengan pendapat Fazlurahman :

"...not only a welcome addition to the exsisting literature on islam but introduces a new approach to the under standing of Islamparticulary by non muslim-the linguistic approach.",

Pendekatan semantik yang dilakukan oleh Toshiko Izutsu merupakan pendekatan baru dalam memahami Islam secara kebahasaan yang dilakukan oleh orang non-muslim. Sehingga beberapa umat Islam menerima penjelasan Toshiko Izutsu mengenai maksud lafaz-lafaz dalam ayat Alquran. Terlebih lagi dia mampu menerjemahkan Alquran ke dalam bahasa Jepang secara akurat yang digunakan umat Islam di jepang pada waktu itu. ${ }^{3}$

1 Aminuddin, SEMANTIK: Pengantar Studi tentang Makna (Bandung: Sinar Baru Algensindo, 1985), 15.

2 Toshiko Izutsu, God and the Man in the Qura'an (Malaysia: Islamic book trust, 1963), dalam sambutan terhadap buku Toshiko Izutsu " God and the man in the Qur'an."

${ }^{3}$ Faisal Hidayah, Hasan Menurut Toshiku Izutsu dalam Buku ethico-relegious concept in the Qur'an dalam Skripsi jurusan Tafsir Hadis, Fakultas Ushuluddin UIN Sunan Kalijaga (Yogyakarta:Fakultas Ushuluddin, 2009), 21.
Iman dan Amal Saleh Dalam Alquran (Studi Kajian Semantik)
Inspirasi Toshiko Izutsu mengenai teori semantik Alquran, diungkapkan oleh Fazlurahman ialah mencoba memahami dari sudut pandang yang berbeda, yaitu dari penggunaan bahasa pada masanya (weltasnchuung), karena bahasa dapat dipahami oleh penutur bahasa itu sendiri. Sehingga istilah-isitlah tertentu (keys-words) yang urgen dapat dipahami dari sudut pandang penggunaan bahasa pada waktu itu. ${ }^{4}$

Secara umum semantik berbeda dengan semantik Alquran dalam hal objeknya. Semantik objeknya ialah bahasa sedangkan semantik Alquran objeknya ialah Alquran yang diyakini sakralitasnya oleh umat Islam. Kajian Izutsu didasarkan pada sejarah nyata kesadaran masyarakat terhadap turunnya Alquran melalui analisa lingkup bahasa Arab dengan memaparkan bagaimana filologi, akustik, psikologi, sosiologi, sejarah yang mendasari terbentuknya suatau jaringan makna yang tidak terpisah tetapi saling berkaitan satu sama lain. ${ }^{5}$

Bahasa mempunyai dua makna yang saling melengkapi yaitu makna dasar (basic meaning) dan makna relasional (relational meaning). Makna yang pertama ialah makna dasar (basic meaning) atau disebut makna leksikal ialah kandungan unsur semantik yang ada pada bentuk kata tersebut dimanapun diletakkan dan digunakan mempunyai makna yang sama. Pada analisis makna dasar ini dapat diketahui secara diakronik dan sinkronik. Sementara makna relasional (relational meaning) ialah suatu makna konotatif ketika ditambahkan pada makna yang sudah ada dengan meletakkan pada posisi khusus. ${ }^{6}$

Setelah makna dasar (basic meaning) dan makna relasional (relational meaning) diketahui, maka langkah terakhir adalah mengatahui apa maksud Alquran atau tujuan

${ }^{4}$ Toshihiko Izutsu, God and the Man in the Qur'an, Dalam sambutan terhadap buku Toshkiu Izutsu "God and the man in the Qur'an"

${ }^{5}$ Mustofa Umar, Konsep Kufur dalam al-Qur'an dan poyeksinya terhadap teks hadis dalam Jurnal alRisalah volume 12, no 1 (Mei: 2012), 45.

6 Toshihiko Izutsu, God and the Man in the Qur'an, 12-13. 
Iman dan Amal Saleh Dalam Alquran (Studi Kajian Semantik)
Alquran (weltanchuung) dengan melihat hubungan kata kunci (key terms) dengan ayat yang menguhubungkannya.

Adapun langkah-langkah dalam kajian semantik Alquran Toshiku Izutsu ialah :

1. Mengumpulkan ayat-ayat yang menjadi kajian sentral

2. Memberikan makna dasar dengan melihat makna sinkronik dan diakronik

3. Memberikan makna relasional

4. Menggunakan teknik welstanchauung dalam memahami konsep kosa kata yang sedang diteliti

5. Mengungkapkan relasi makna iman dan amal saleh dalam pandangan semantik ${ }^{7}$

\section{MAKNA IMAN DAN DERIVASINYA}

\section{Makna Dasar}

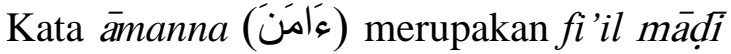
terulang 31 kali yang berarti keyakinan atau telah yakin. Kata ini merupakan akar kata dari berbagai bentuk deriviasi seperti; kata àmanat (أمَنَتْن terulamg 5 kali berarti dia telah beriman (menunjukan mu'annath), kata amantu (أمَنْتُُْن berarti aku telah percaya terulang 3 kali, kata àmannāa (أمَنَا) terulang 33 kali berarti kami telah percaya, kata amanahum (آََنَهُْمَ) terulang1 kali berarti telah

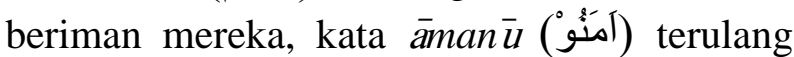
174 kali berarti mereka telah beriman, kata

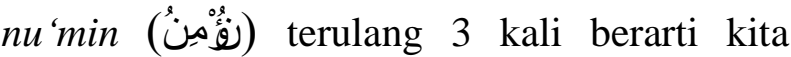

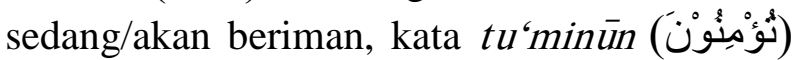
terulang 8 kali berarti kalian sedang/akan beriman, kata tu'min (تؤمن) terulang 12 kali berarti kamu akan/sedang beriman, dan kata yu'min (يُؤْنَن) terulang 85 kali berarti dia sedang/akan beriman. ${ }^{8}$

Adapula kata mu'minūn (مؤمنون), kata mu'minin (مؤمنين), kata mu'minān (مؤمنان) berarti orang-orang beriman, kata al-İmānu (الإيمان) dan kata imānān (إيمانا) berarti keyakinan yang semuanya berasal dari kata

7 Toshihiko Izutsu, God and the Man in the Qur'an, 4-11.

${ }^{8}$ Mahmud Yunus, Arab Indonesia ( Jakarta: Mahmud Yunus Wa Dzurriyah, 1989), 49. āmina (أمنَ) yang berarti aman, damai, sentosa. ${ }^{9}$

Dalam kamus Lisān al-'Arab kata iman mempunyai beberapa arti yaitu perasaan takut (ضدّالخوف), perasaan khianat

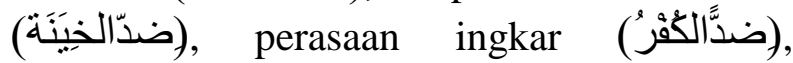
membenarkan (النَّنْدِيْقُ), dan keyakinan untuk

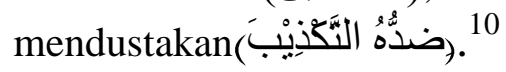

Sedangkan kata iman yang asal katanya āmina (َاعَ) mempunyai arti aman atau tentram, selain itu ada juga kata yang berdekatan yaitu amānatan (أمانة) yang berarti jujur yang asal katanya ialah àmuna (أمنَنَ).11 Ketiga asal kata ini menunjukan kesamaan makna bahwa kata āmina (عَامن) menunjukan keyakinan seseorang ditimbulkan karena pengetahuan yang didapat, yang menghasilkan sifat amānat (أمانة) dalam keyakinannya, sehingga timbul ketentraman dalam kehidupannya.

\section{Sinkronis dan Diakronis Makna Iman}

Sinkronis dan Diakronis merupakan bagian dari pendekatan semantik dengan tujuan untuk mengetahui bagaimana penggunaan bahasa kata iman dari masa praIsalam dan pasca-Islam, serta bagaimana aplikasi penggunaan iman tersebut.

Kata iman dalam pengunaan orang-orang Arab merupakan keyakinan kepada hal apapun yang dianggap supranatural yang dapat melindungi seluruh manusia. Pada masa praIslam terdapat berbagai keyakinan seperti menyembah bulan, binatang, bahkan ada yang ateis karena hanya mengikuti tradisi nenek moyang, kebanyakan orang-orang Baduy. Sedangkan di Mekkah mayoritas mereka adalah penyembah berhala (watsāniyyah). Sedikit orang yang mengikuti ajaran Ibrahim

\footnotetext{
${ }^{9}$ Muḥammad Fu'ād, 'Abd al-Bāqìi, Al-Mu'jam AlMufahras, 88-90. dan Mahmud Yunus, Arab Indonesia, 49.

${ }^{10}$ Ibn Manzūr, Lisān al- 'Arab (Mesir: Dār alMa‘ārif, $1991 \mathrm{H}), 140$.

${ }^{11}$ Adib Bisri dan Munawwir, Kamus Indonesia Arab: Arab Indonesia (Yogyakarta: Pustaka Progresif, 1999), 16.
} 
( الدين حنيفة ), dan agama samawi seperti Nasrani dan Yahudi. ${ }^{12}$

Penggunaan kata iman oleh orang-orang Arab sebagai keyakinan terhadap hal yang supranatural, tanpa mengkhususkan makna iman terhadap agama tertentu, terlihat dari syair berikut ini :
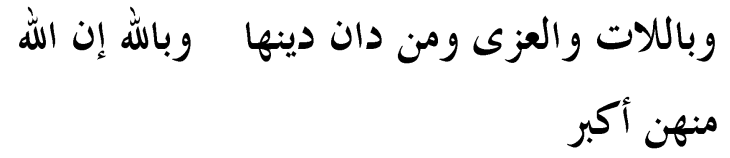

“ Demi Lâtta dan 'Uzzà dan orang-orang yang mempercayainya, Demi Allah sesungguhnya Allah lebih agung dari mereka" 13

Ini merupakan syair yang diungkapkan oleh Zuhair ibn Sulmā mengenai keimanan orang-orang Arab terhadap berhala-berhala, khususnya Lātta dan 'Uzza. Makna iman pada syair tersebut menggunakan kata al-Din (الدين) yang berarti keparcayaan. Makna iman juga digunakan oleh agama samawi, khususnya agama Yahudi, seperti syair berikut ini:

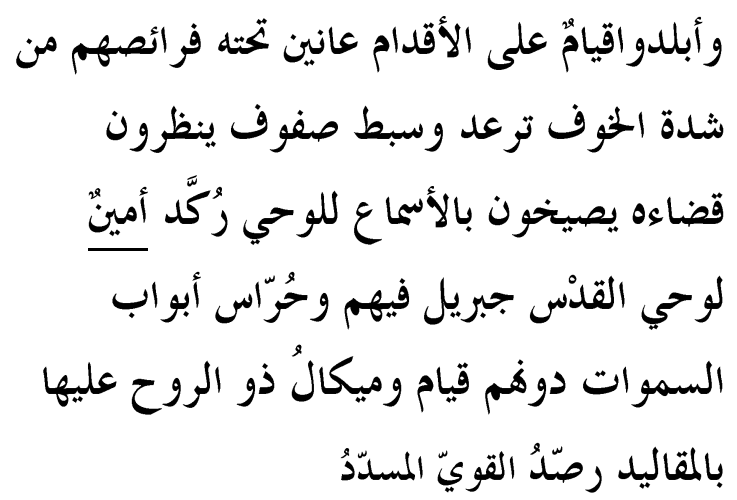

"Wahai Tuhan kami, bagi-Mu segala puji, kenikmatan dan kekuasaan. Tidak ada sesuatu pun yang lebih tinggi dan mulia dari-Mu. Di bawah Arsy-Nya kaki-kaki Malaikat. Demi kedua telapak tanganNya, jika bukan karena Allah, mereka pasti letih dan lemah. Tampak nyata berdiri dengan kaki di bawah Arsy. Tubuhnya bergetar karena sangat takut. Berbaris

\footnotetext{
${ }^{12}$ Cahya Buana, Nilai-Nilai Moralitas dalam Syair Jahiliyyah dalam Jurnal Buletin Ituras, volume XXIII no. 1(Januari, 2017, ISSN. 08531692), 93-94.

${ }^{13}$ Cahya Buana,Nilai-Nilai Moralitas dalam Syair Jahiliyyah, 94.
}

Iman dan Amal Saleh Dalam Alquran (Studi Kajian Semantik) dengan rapi, menunggu keputusannya. Mendengarkan wahyu dengan tenang.

Yang dapat dipercaya untuk (mengemban) wahyu yang suci, di antara mereka Jibril dan Mikail yang memiliki ruh yang sangat kuat lagi benar dan para Malaikat penjaga pintu-pintu langit di bawahnya berdiri di atasnya, mengawasi dengan cermat" $" 14$

Kata iman tersebut pada masa pra-Islam digunakan sebagai simbol keyakinan hati terhadap apa-apa yang telah disampaikan mengenai keagungan Tuhan, ataupun hal-hal yang spiritual. Maka ketika Islam datang kata iman digunakan sebagai keyakinan hati terhadap kekuasaan dan kebenaran Tuhan, dengan tanda-tandanya dan merubah ha-hal yang esensi mengenai keyakinan-keyakinan penyembah berhala. Agama samawi seperti Nasrani dan Yahudi. Seperti Alquran membantah bahwa Allah mempunyai anak dalam QS. Al-Najm [53]:19-22.:

$$
\begin{aligned}
& \text { أَفَرَأَيْتُ ُ اللَّاتَ وَالْعُزَّى (19) وَمَنَاةَ الثَّالثَنَة }
\end{aligned}
$$

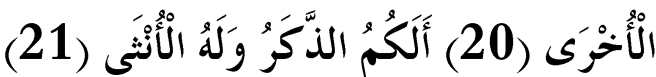

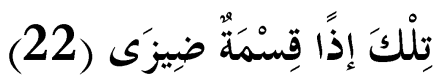

"Apakah layak kalian (Hai orang-orang musyrik) mengaggap al-Làta dan al'Uzzā dan Manah yang kemudiN (sebagai anak perempuan Allah)? Apakah layak untuk kalian anak laki-laki dan untuk Allah anak perempuan? demikian itu suatu pembagian yang tidak adil."

Bantahan Alquran terhadap Yahudi dan Nasrani mengenai 'Uzair dan Isa adalah anak Allah dalam QS. Al-Taubah [9]: 30.:

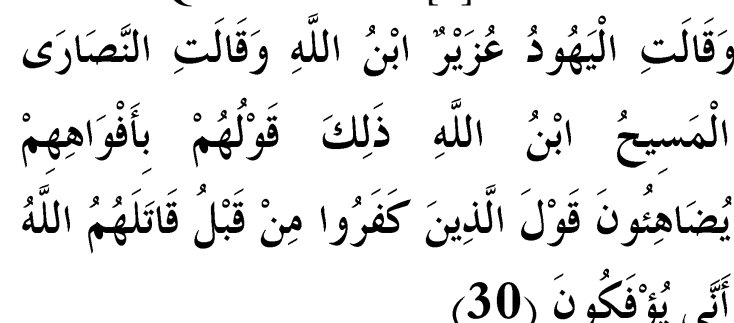

"Orang-orang Yahudi berkata:" 'Uzair itu anak Allah' dan orang-orang Nasrani

${ }^{14}$ Shauq Daif, Tärikh al- 'Adab al- 'Arab; al- 'Ashr al-Jahil, Cet. 2 (tp: Dār al-Ma‘ārif, 1965), 122. 
Iman dan Amal Saleh Dalam Alquran (Studi Kajian Semantik) berkata: 'Al-Masih itu anak Allah'. Demikianlah ucapan dengan mulut mereka, yang meniru perkataan orangorang kafir terdahulu. Allah melaknat mereka, bagaimana sampai berpaling?"

Sehingga proses keimanan ditinjau dari diakronik yaitu yang pertama iman bermakna meluruskan akidah dengan mempercayai kekuasaan Allah, yang kedua yaitu penguatan akidah dengan janji dan ancaman, serta selalu mengajak kepada kebaikan dengan dakwah yang halus. Ketiga bemakna pelaksanaan ibadah yang diterapkan secara bertahap, bergaul dengan mesyarakat dan melaksanakan hukum-hukum yang diperintahkan.

\section{Makna Relasional}

Pebedaan penggunaan kata iman dalam Alquran dapat ditinjau dari dua bentuk yaitu fi'il mădị dan fi'il muḍarāi yang mempunyai penekanan dan maksud yang berbeda, seperti

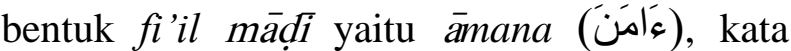

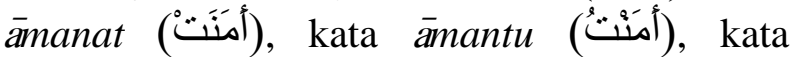

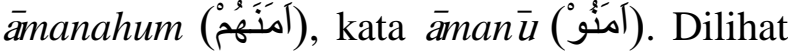
dari subyek orang-orang beriman dapat ditujukan kepada sahabat masa nabi, Ahl alKitab, Orang-orang beriman terdahulu dan orang-orang kafir. Sedangkan dalam Bentuk

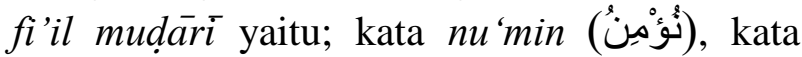

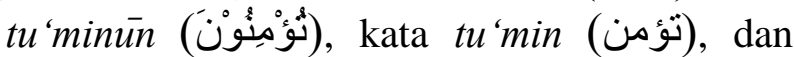
kata yu'min (يُوْْنَنُ) menunjukan makna seseorang telah beriman tetapi masih ada keraguan, khususnya terhadap hal-hal gaib yang sulit dipahami akal dan indra, seperti dalam surah al-Baqarah ayat 3 yang menjelaskan kata yu'min (يُوْْنَ) mengenai hal gaib:

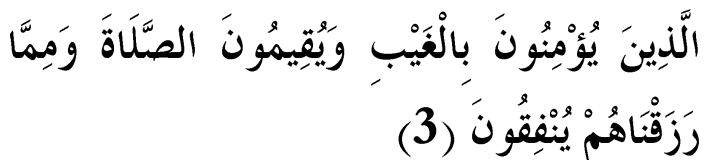

“ (Yaitu) Mereka yang beriman kepada yang gaib, yang mendirikan salat, dan menafkahkan sebagian rezeki yang kami anugerahkan kepada mereka",15

Lalu QS. Al-Baqarah[2]:260.

\footnotetext{
${ }^{15}$ Kementrian Agama, Al-Qur'an dan
} Terjemahnya, 8.

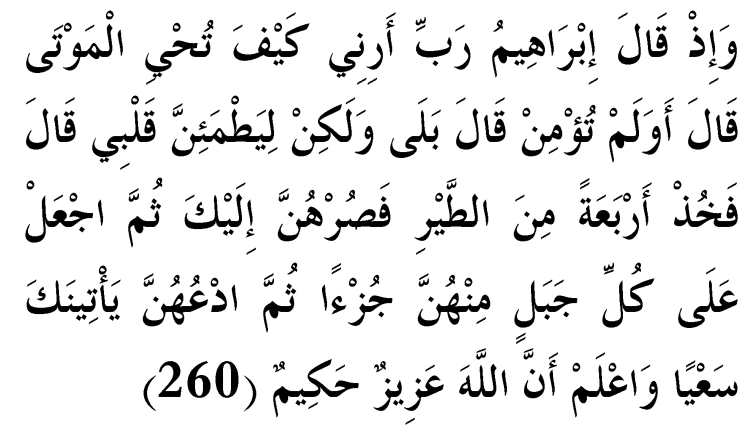

"Ibrahim berkata: 'Ya Tuhanku, perlihatkanlah kepadaku bagaimana engkau menghidupkan orang-orang mati.' Allah berfirman: 'Belum yakinkah kamu? Ibrahim menjawab: 'Aku telah meyakinkannya, akan tetapi agar hatiku tetap mantap (Dengan imanku).' Allah berfirman: '(Kalau demikian) Ambillah empat ekor burung, lalu cincanglah semuanya olehmu'. (Allah berfirman): 'Lalu letakkan di atas tiap-tiap satu bukit satu bagian dari bagian-bagian itu, kemudian panggillah mereka, niscaya mereka datang kepadamu dengan segera.' Ketahuilah bahwa Allah Maha Perkasa lagi Maha Bijaksana.,",16

Kata awalam tu'min ( أولم تؤهن ) bukan berarti Nabi Ibrahim tidak beriman kepada Allah Swt, tetapi keimanannya masih terdapat keraguan. Oleh karena itu perlu pembuktian untuk meyakinkan keimanannya. Sehingga keimanan dalam bentuk fi'il mudărīi ialah proses keiman yang telah ada yang perlu dibuktikan kembali untuk memberikan keyakinan yang kuat, seperti skema 1:

Iman dalam bentuk fi'il mudârīi selalu dihubungkan dengan kata Allah dan hari akhir diantaranya al-Nisā[4]:59, al 'An' àm[6]:150, al-Taubah[9]:29, 44, 45, Yüsuf[12]: 37, alNahI16]:22, 60, al-Isrā[17]:10, alMu'minūn[23]:74, al-Nür[24]:2 , alNaml[27]:4, Saba[34]:8, al-Najm[53]:27, Mujadalah[58]:22, keimanan kepada Allah digandengkan dengan hari akhir.

\footnotetext{
${ }^{16}$ Kementrian Agama, Al-Qur'an dan Terjemahnya, 65 .
} 


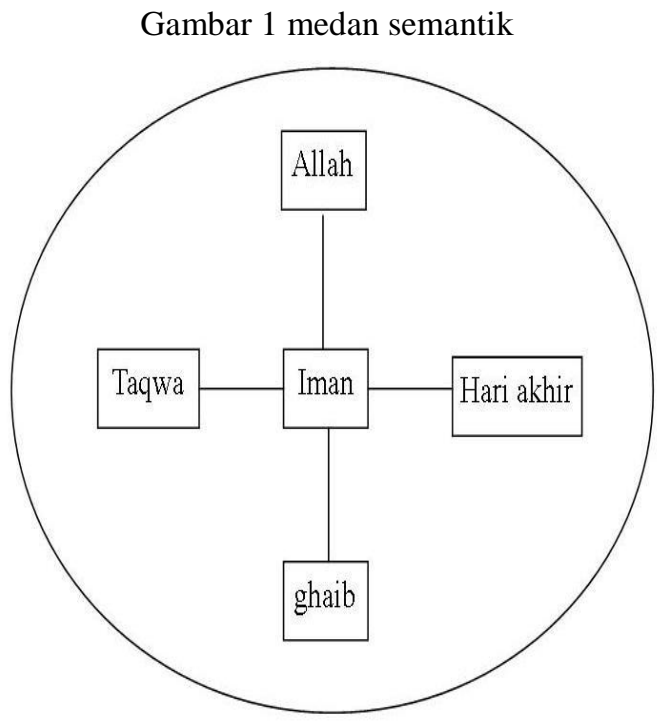

Kata iman dalam bentuk fi'il mādi lebih menekankan dalam praktik ibadah dan perbuatan baik, tetapi kata iman dalam bentuk fi'il muḍāri lebih menekankan kepada hal-hal gaib, hari akhirat dan ketakqwaan, hal ini karena bentuk fi'il muḍāri menunjukan seseorang telah mempunyai keimanan tetapi masih meragukan keimanan terhadap hal-hal yang tidak dapat dipahami oleh akal pikiran atau panca indra, sehingga perbuatan amal saleh dalam bentuk fi'il mậ̣i sama dengan

Gambar 2 perbedaan kata iman dalam bentuk fi'il mädì dan fi' il mudâri

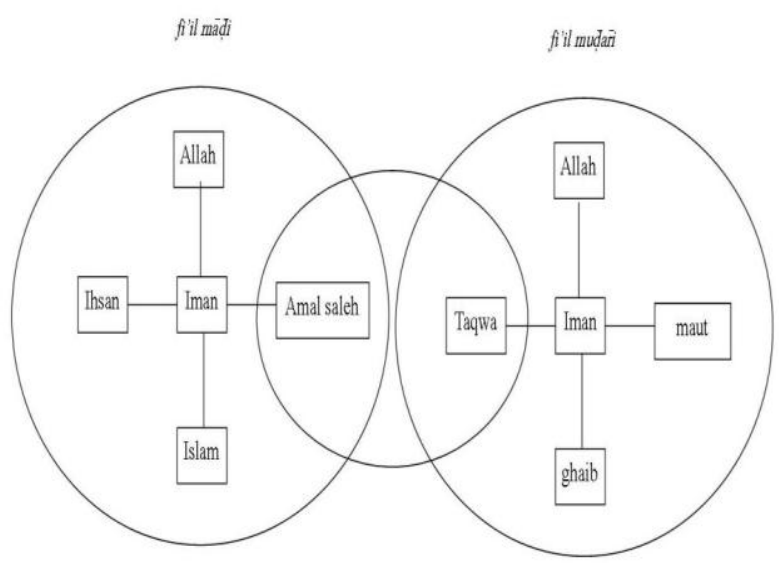

taqwa dalam bentuk fi'il muḍāri.

Maka kata iman dapat menunjukan makna yang positif dan makna yang negatif seperti skema berikut ini:
Iman dan Amal Saleh Dalam Alquran (Studi Kajian Semantik)

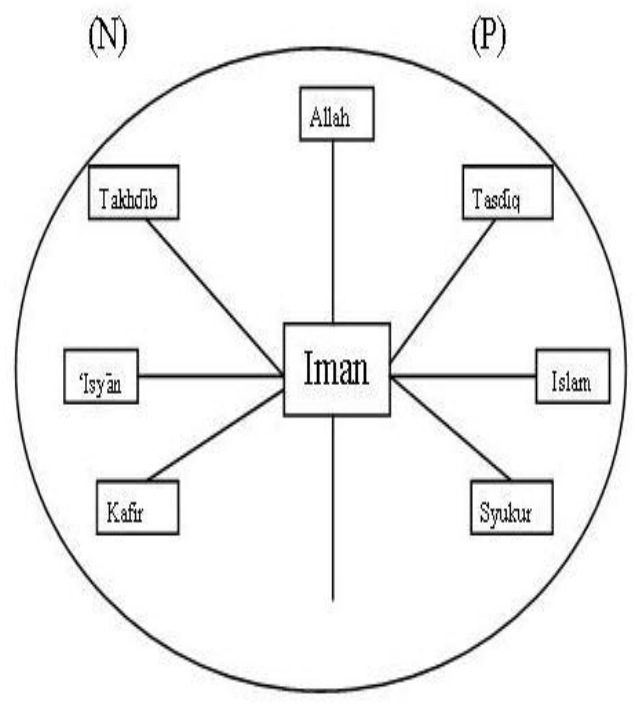

Dalam makna positif iman menunjukan tạsdiq (تصديق) yang berarti keyakinan yang teguh kepada Allah, kata Islam yang berasal dari kata aslama (أسلم) berarti berserah diri kepada Allah dan kata shukür (شكور) berarti berterima kasih atas karunia yang di berikan, karena asal katanya ialah shakara (شكر). Sedangkan makna yang negatif dari iman yang menunjukan kebalikannya seperti kata kafir (كفر) yang berarti tidak percaya, kata 'isyān (عصبان) yang berarti nifak yaitu menujukan keimanan di depan tetapi di dalam hatinya meragukan, dan kata takhdib (تكذيب) berarti memberikan kebohongan terhadap perkataanya. $^{17}$

Sedangkan orang-orang yang mengingkari keimanan seperti orang-orang kafir dan Ahl al-Kitab mempunyai sifat-sifat negatif kepada Allah Swt, yaitu; kata 'isyān (عصيان) yang berarti nifak yaitu menujukan keimanan di depan tetapi di dalam hatinya meragukan, dan kata takhdib (تكذيب) berarti memberikan kebohongan terhadap perkataanya, syirik yaitu menyekutukan Allah, istikbār (استكبار) yaitu menyombongkan diri baik kepada Allah ataupun pada sesama manusia, zulm (ظلم) berarti bertindak lalim atau aniaya, dalalāl (ضلالا) berarti tersesat

\footnotetext{
${ }^{17}$ Toshiku Izutsu, Semantik al-Qur'an, 23.
} 
dan fásik (فاسك) ialah orang yang mengaku iman dan Islam tetapi tidak melaksanakan apa yang diperintahkan agama. ${ }^{18}$

\section{MAKNA AMAL SALEH DAN DERIVASINYA}

\section{Makna Dasar}

Kata amal dalam Alquran terbagi menjadi empat variasi bentuk yaitu isim, fi'il māọi , fi'il mudârí dan fi'il amr. Adapun bentuk isim

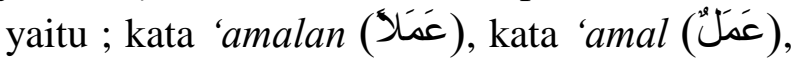
terulang 9 kali, kata a mal (أعْمَالَ" (أعَ), kata a'malan (أعْمَالأ) terulang 1 kali berarti

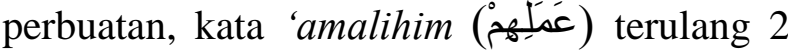

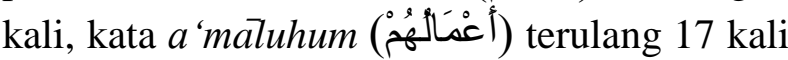
berarti perbuatan mereka, kata 'amali (عَلِيَ) terulang 1 kali perbuatan saya, kata a'malukum (أعَمَأكَْمْ) terulang 22 kali berarti perbuatan kalian, kata 'amil (عَاملِ) terulang 4 kali berarti yang berbuat, kata 'ámilün (عَامِلْونْن) terulang 4 kali berarti mereka yang berbuat, kata 'amilah (عَامِلِّ) terulang 1 kali berarti yang berbuat dan kata al-'amilin (العَامِلِيْنَ) terulang 4 kali berarti orang yang melakukan perbuatan. ${ }^{19}$

Bentuk fi'il mậ̣i yaitu; 'amila (عل) terulang 19 kali yang berarti berbuat kata 'amiltu (عَمِلتِ (عَ) terulang 5 kali berarti aku telah

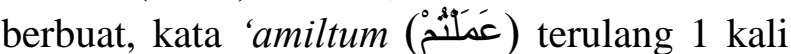
berarti kalian telah berbuat, kata amiltahu (عَلَ) terulang 1 kali berarti kamu telah berbuat terhadapnya, kata 'amilu- (عَمَّوا') terulang 73 kali berarti mereka telah berbuat, kata a'mal (أعْمَلُْ (َ) berarti telah berbuat,

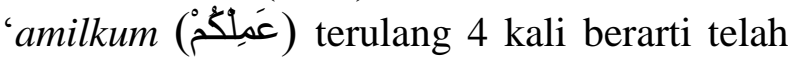
berbuat kalian, 'amalih (عَمَلِهِ) terulang 5 kali berarti perbuatannya. ${ }^{20}$

Bentuk fi'il muḍārī yaitu ; kata ta 'mal (تَعْدَلُْ sedang/akan berbuat, kata ta malūn (تَعْمَلْونَ)

${ }^{18}$ Toshiku Izutsu, Semantik al-Qur'an, 25

${ }^{19}$ Mahmud Yunus, Arab Indonesia, 281.

${ }^{20}$ Mahmud Yunus, Arab Indonesia, 281 dan Muhammad Fu'ād 'Abd al-Bāqì, Al-Mu'jam AlMufahras, 483-488.
Iman dan Amal Saleh Dalam Alquran (Studi Kajian Semantik)

terulang 82 kali berarti kalian akan/sedang berbuat, kata na'mal (نَعْمَكَ) terulang 6 kali berarti kita sedang/akan berbuat, kata ya 'mal (يَعْمَلُ) terulang 14 kali berarti dia sedang/akan berbuat, kata ya 'malun (يَعْمَوْنَ) terulang 56 kali yang berarti mereka sedang/akan berbuat.

Bentuk fiil amr yaitu; kata a mal (أعْدَ') terualang 4 kali berarti berbuat baiklah kalian (perintah kepada satu orang), kata $a^{\prime} m a l \bar{u}$ (أعْمَلْوَ) terulang 9 kali berarti berbuatlah (perintah kepada orang banyak) $^{21}$

Sedangkan untuk kata saleh terbagi menjadi empat bentuk derivasi yaitu $i s i m$, fi' $i l$ mặdi, fi'il muḍarī dan fi'il amr. Adapun bentuk isim yaitu kata aslaḥa (أصلحا) terulang

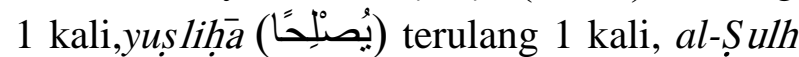

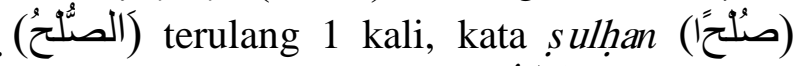
berarti kebaikan, kata $s$ alih (صنَالِحْ (ص) terulang 8 kali, kata sâlihan (صَّلالِحًا) terulang 36 kali berarti orang yang berbuat baik, kata sălihain (صَالِحَنْن) terulang 1 kali berarti dua orang yang berbuat baik, kata al-Ṣalihìn (الصنَّالِحِيْنَ) terulang 24 kali berarti orang-orang yang

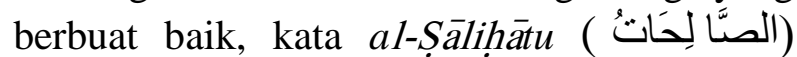

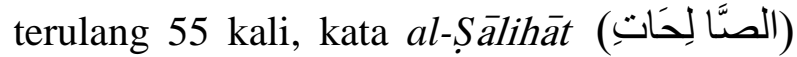
terulang 7 kali berarti perempuan-perempuan yang berbuat baik, kata islah (إصنام) terulang 3 kali , kata islạhan (إصنأ) terulang 2 kali berarti perbaikan, kata islahiha (إصنالخحهَ) terualang 2 kali berarti perbaikan terhadapnya,kata al-musliḥ (المُصِْْحُح) terulang 1 kali orang yang melakukan kebaikan, kata

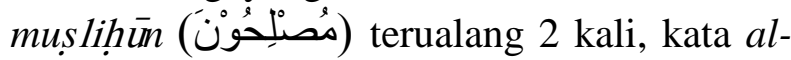
muslihin (المَصنِلِحِيْنَ) terulang 2 kali berarti orang-orang yang melakukan kebaikan. ${ }^{22}$

Bentuk fi'il mạại yaitu; kata salaha (صلّح) terulang 1 kali, kata aslaha (أصنّح) terulang 8 kali berarti telah melakukan kebaikan. Bentuk fi'il mudârī yatu; kata tuslihū (نُصنِلْحُون) terulang 1 kali berarti kalian sedang/akan melakukan kebaikan, kata yus lih

\footnotetext{
${ }^{21}$ Mahmud Yunus, Arab Indonesia, 281.

${ }^{22}$ Mahmud Yunus, Arab Indonesia, 3107-3108 dan Muhammad Fu'ād 'Abd al-Bāqì, Al-Mu'jam AlMufahras, 410-412.
} 
(يُصنِحْحُ) terulang 3 kali berarti sedang/akan melakukan kebaikan, kata yusliḥun (يُصْلِحُوْنَ) terulang 2 kali berarti mereka berbuat baik dan bentuk fi'il amr yaitu; kata asliḥu (أصنالِحُوْ) terulang 4 kali berarti kalian perbaikilah, kata aslah (أصنْحْ) terulang 2 kali berarti perbaikilah.

Dalam Lisān al-'Arab kata 'amal (عل) mempunyai arti perkerjaan (المِيْنَة), perbuatan

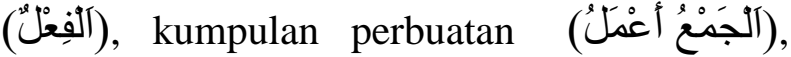

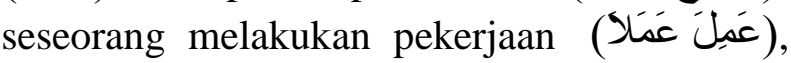

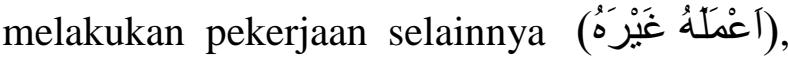
mempergunakannya

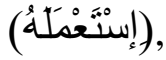

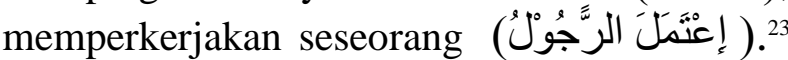
Sedangkan menurut Raghib al-Asfahāni makna kata amal adalah semua pekerjaan yang berasal dari makhluk hidup dan dilakukan dengan sengaja. ${ }^{24}$ Karena kata amal merupakan akar suatu kata yang menunjukkan pada satu makna yang sama, yaitu semua pekerjaan yang dilakukan. ${ }^{25}$

Sehingga apapun yang dikerjakan makhluk hidup baik itu manusia, hewan dan tumbuhan merupakan amal. Dan amal yang dilakukan manusia sangat luas baik itu belajar, bekerja, membantu orang tua, bermain ataupun yang lainnya, semuanya menunjukan amal karena amal merupakan suatu pekerjaan yang disengaja baik itu menimbulkan maslahat ataupun mudarat.

Adapun kata șalih (صالح) mempunyai makna diantaranya baik (طيب), bagus (ضدَُّسَدًا), kumpulan kebaikan (الجمع صلحاء), seseorang yang saleh terhadap kelompoknya (رجل صالح في نفسـ من قوم صلحاء) , perbuatan yang baik terhadap perilaku dan pekerjaanya

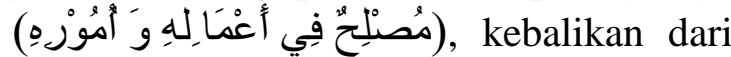

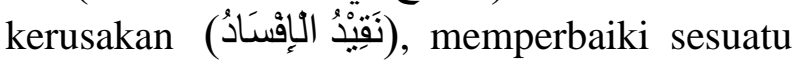

${ }^{23}$ Mahmud Yunus, Arab Indonesia, 3107-3108 dan Muhammad Fu'ād 'Abd al-Bāqī, Al-Mu'jam AlMufahras, 410-412.

${ }^{24}$ Raghib al-Asfahani , Al Mufradāt Fì Gharib al Qur'ān (Mesir: Darul Ma'rifat, t.t), 351.

${ }^{25}$ Abi Husain Ahmad ibn Fāris ibn Zakaryā, Mu ‘jam Maqāyis al-Lughah (Mesir :Dār al-Kutb 'Alamiyah, t.t), 1-17.
Iman dan Amal Saleh Dalam Alquran (Studi Kajian Semantik) setelah rusak

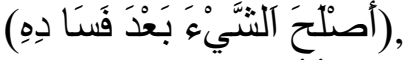

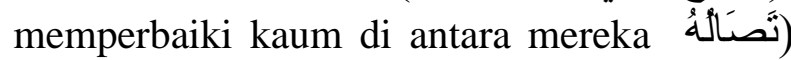

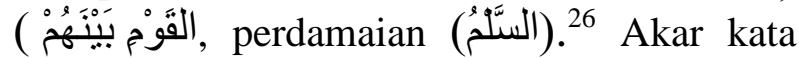
saleh menunjukkan pada satu makna yang sama yaitu lawan dari kerusakan, sehingga saleh ialah perbuatan baik yang dipandang oleh agama dan manusia. ${ }^{27}$

\section{Sinkronis dan Diakronis makna amal saleh}

Perbuatan amal saleh telah dilakukan oleh orang-orang Arab pra-Islam dengan menunjukan suatu perbuatan baik yang didalamnya ingin mendapatkan pahala atau keuntungan dari Tuhan, yang dirasakan kebermanfaatan oleh masyarakat baik dari perilaku, sikap dan perasaan.

Kata amal saleh pasca-Islam diperkuat oleh al-Quran dengan keimanan terhadap Allah Swt, maka amal saleh tersebut harus dilandasi keimanan kepada Allah Swt, tetapi jika tidak dilandasi keimanan maka tidak dapat disebut amal saleh.

Makna diakronis amal saleh pasca-Islam dapat dilihat dari proses turunyya al-Quran dari Makiyyah dan Madaniyyah dapat terlihat menjadi tiga proses pemaknaan, yaitu: Pertama ialah amal saleh yang bermakna perbuatan baik yang mendapatkan surga, mendapatkan kenikmatan, dan janji. Kedua amal saleh berarti perbuatan baik yang tingkatannya sama seperti ibadah, karena amal saleh dapat berbentuk ibadah kepada Allah. Ketiga amal saleh yang menunjukan perbuatan sosial luar biasa dari mengeluarkan harta, berjuang dijalan Allah, dan mengembangkan Islam.

\section{Makna Relasional}

Kata amal bermakna suatu perbuatan dapat dilihat dari segi yang baik atauapun yang buruk. Dari segi yang baik maka digandengkan dengan saleh, sedangkan yang buruk digandengkan dengan $s \bar{u}$ sayyiat dalam QS. Al-Nahı[16]:97, Al-An‘'àm[6] : 54, Al$M u ' \min [40]: 40$;

\footnotetext{
${ }^{26}$ Ibn Manzūr, Lisān al-'Arab, 2479.

${ }^{27}$ Abi Husain Ahmmad ibn Fāris ibn Zakarya, Mu jam Maqāis al-Lughah, 1-17.
} 


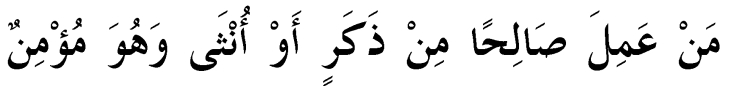

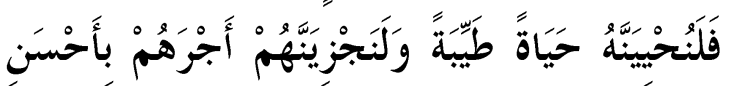

مَا كَانُو ا يَعْمَلُونَ (97

“ Barangsiapa yang mengerjakan amal saleh, baik laki-laki maupun perempuan dalam keadaan beriman, maka sesungguhnya akan kami berikan kepadanya kehidupan yang baik dan sesungguhnya akan kami beri balasan kepada mereka dengan pahala yang lebih baik dari apa yang telah mereka kerjakan. "28

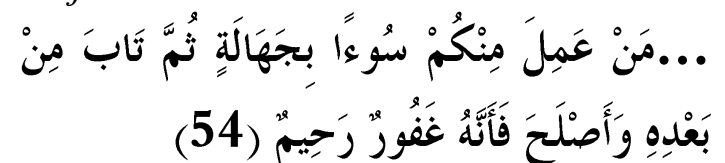

"...bahwasanya barang siapa yang berbuat kejahatan di antara kamu lantaran kejahilan, kemudian dia bertaubat setelah mengerjakannya dan mengadakan perbaikan, maka sesungguhnya Allah Maha Pengampun lagi Maha Penyayang. "29

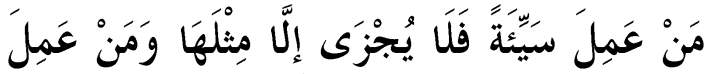

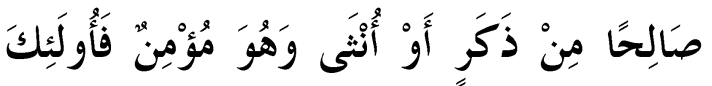

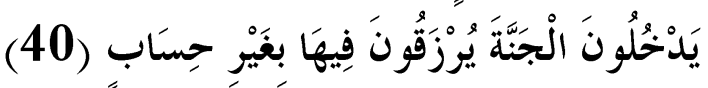

"Barangsiapa mengerjakan perbuatan jahat, maka dia tidak akan dibalasi melainkan sebanding dengan kejahatan itu. Dan barangsiapa mengerjakan amal yang saleh baik laki-laki maupun perempuan sedang dia dalam Keadaan beriman, Maka mereka akan masuk surga, mereka diberi rezeki di dalamnya tanpa hisab. "30

Adapun kata saleh mempunyai beberapa bentuk diantaranya; fi'il mā d̦i yaitu kata salaha ( صَّلحَ), dan kata aslaha (أصنلحَ),

\footnotetext{
${ }^{28}$ Kementrian Agama, Al-Qur'an dan
} Terjemahnya, 417

${ }^{29}$ Kementrian Agama, Al-Qur'an dan Terjemahnya, 195.

${ }^{30}$ Kementrian Agama, Al-Qur'an dan Terjemahnya, 769.
Iman dan Amal Saleh Dalam Alquran (Studi Kajian Semantik)

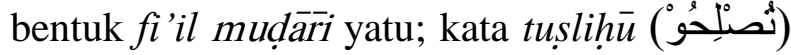

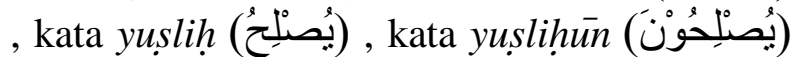
dan bentuk fi'il amr yaitu; kata aslihū

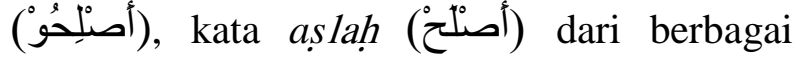
bentuk derivasi kata saleh menunjukan makna kebaikan dari perbuatan, pikiran dan akhlak. Sehingga makna amal saleh menunjukan perbuatan baik yang berlandaskan keimanan, karena kata amal saleh selalu digandengkan dengan iman, seperti dalam QS.al'Așr[103]:3:

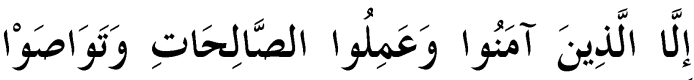

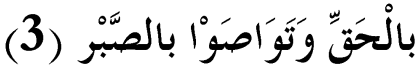

"Kecuali orang-orang yang beriman dan mengerjakan amal saleh dan nasehat menasehati supaya mentaati kebenaran dan nasehat menasehati supaya menetapi kesabaran" "31

\section{E. WELTANSCHUUNG}

Penempatan kata iman dan amal saleh mempunyai kedudukan penting dalam Alquran. Karena dua hal ini saling mengisi antara satu dan yang lainnya. Iman merupakan konsep keyakinan terhadap Allah Swt, sedangkan amal saleh merupakan perbuatan baik yang berlandaskan keimanan. Bahkan Nabi menggambarkan bahwa amal saleh itu sebagai penyempurna keimanan, sebagaimana dalam Hadith :

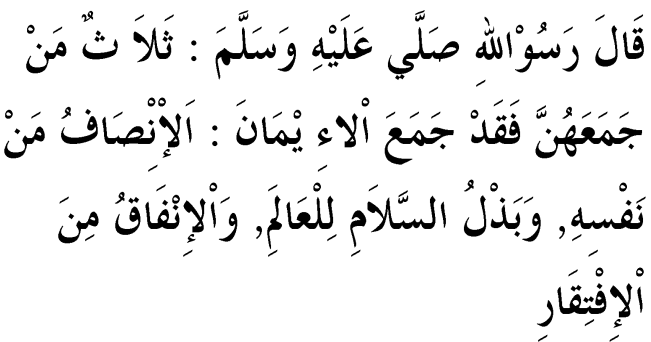

'Rasulullah Saw, bersabda '(Perhatikan) tiga hal : Barang siapa yang sanggup menghimpunnya niscaya akan mencakup iman yang sempurna. Yakni : (1) Jujur terhadap diri sendiri, (2). Mengucapkan salam perdamain kepada seluruh dunia

\footnotetext{
${ }^{31}$ Kementrian Agama, Al-Qur'an dan Terjemahnya, 1099.
} 
Iman dan Amal Saleh Dalam Alquran (Studi Kajian Semantik) dan (3) mendermakan apa yang menjadi kebutuhan umum,"'.

Dari Hadith di atas amal saleh yang dilakukan ialah 1). Jujur terhadap diri sendiri, 2). Mengucapkan salam dan 3). Mendermakan sebagian harta. Adapun Hadith yang menjelaskan bahwa tidak beriman seseorang jika tidak melakukan amal saleh yaitu :

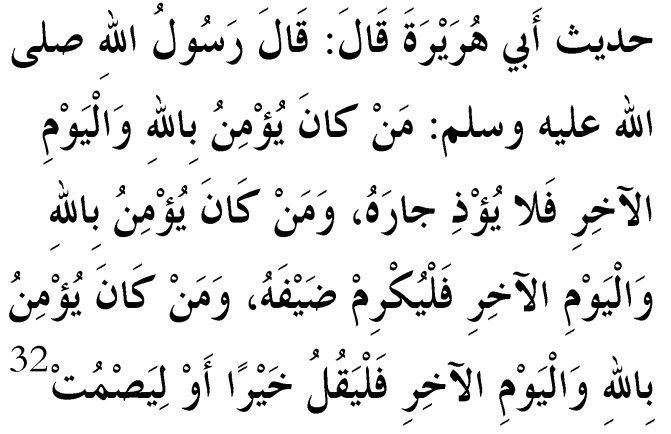

Abu Hurairah R.A. berkata: Rasulullah Saw, bersabda: " Siapa yang percaya (beriman) kepada Allah dan hari kemudian, maka jangan mengganggu tetangganya. Dan siapa yang beriman kepada Allah dan hari kemudian, maka harus menghormat (menjamu) tamu-nya. Dan siapa yang beriman kepada Allah dan hari kemudian maka hendaknya berkata baik atau diam"

Hadith ini menegaskan siapa yang yakin atas keimanan kepada Allah dan hari akhir maka perlu melakukan amal saleh, yaitu tidak menganggu tetangganya, menghormati tamu dengan menjamunya dan berkata yang baik. Sehingga tidak sempurna imannya jika mengganggu tetangganya, tidak menghormati tamunya dan berkata-kata yang tidak baik.

Amal saleh mempunyai pengertian yang luas baik yang berhubungan dengan Allah Swt, sesama manusia, diri sendiri dan alam semesta. Sehingga bentuk amal saleh dapat berupa pikiran, tenaga dan pemberian harta benda. Adapula yang berupa ucapan dan tingkah laku yang baik dalam kehidupan dan pergaulan sehari-hari. ${ }^{33}$

32 Muhammad Fu'ād 'Abd al-Bāqi, Lulu' wa alMarjān, juz.1(Mesir: Baith al-Fikr, t.t), 10 atau dalam kitab Sahih Bukhāri, bab. Adab : no.31.

33 Fachruddin H S, Ensklopedia al-Qur'an, Jilid.1(Jakarta: Rineka Cipta, 1992), 95.

\section{F. SIMPULAN}

Hasil dari penelitian menunjukan bahwa kata iman dan amal saleh dalam kajian semantik mempunyai kedudukan penting dalam Alquran, karena dua hal ini saling mengisi antara satu dan yang lainnya. Iman merupakan konsep keyakinan terhadap Allah Swt, sedangkan amal saleh merupakan perbuatan baik yang berlandaskan keimanan. Kata amal saleh mempunyai pengertian yang luas baik yang berhubungan dengan Allah Swt, sesama manusia, diri sendiri dan alam semesta. Sehingga bentuk amal saleh dapat berupa pikiran, tenaga dan pemberian harta benda. Adapula yang berupa ucapan dan tingkah laku yang baik dalam kehidupan dan pergaulan sehari-hari, keluasan makna amal saleh merupakan pengokoh keimanan terhadap Allah Swt, maka iman dan amal saleh tidak dapat dipisahkan.

\section{DAFTAR PUSTAKA}

'Abd al-Bāqi, Muhammad Fu'ād . Lüū wa alMarjān, juz.1,(Mesir: Baith al-Fikr t.t) .Al-Mu 'jam

al-Mufahras Li al-Fāz al-Qur'ān al-Karìm . Mesir: Dār al-Kutb limișriyyah, 1364 H.

Adib Bisri dan Munawwir, Kamus Indonesia Arab:Arab Indonesia. Yogyakarta: Pustaka Progresif, 1999.

al-Asfahani , Raghib .Al Mufradāt Fī Gharib al Qur 'àn. Mesir: Darul Ma'rifat, t.t.

al-Hajjaj , Muslim ibn, Șahih Muslim, jilid.1, Bab.Iman, No Hadis.1. Beirūt :Dār Ihỵā al-Tarath al-'Arab,t.t.

Aminuddin,

SEMANTIK

Pengantar Studi tentang Makna. Bandung: Sinar Baru Algensindo,1985.

Cahya Buana, Nilai-Nilai Moralitas dalam Syair Jahiliyyah dalam Jurnal Buletin Ituras, volume XXIII no 1. Januari 2017,ISSN.08531692.

H S. Fachruddin , Ensklopedia al-Qur'an. Jilid.1. Rineka Cipta : Jakarta. 1992.

Hidayah, Faisal. Hasan Menurut Toshiku Izutsu dalam Buku ethico-relegious concept in the Qur'an dalam Skripsi jurusan Tafsir Hadis, Fakultas Ushuluddin 
UIN Sunan Kalijaga. Yogyakarta: Fakultas Ushuluddin, 2009.

Izutsu, Toshiko. God and the Man in the Qura'an. Malaysia: Islamic book trust. 1963.

Kementrian Agama RI, Al-Qur'an \& Tafsirnya (edisi yang disempurnakan), jilid 9. Jakarta: Widiya, 2011. , Al-Qur'an \& Tafsirnya (edisi yang disempurnakan), jilid 4. Jakarta: Widiya, 2011.

, Al-Qur'an \& Tafsirnya (edisi yang disempurnakan), jilid 2, 334.

Kementrian Agama, Al-Qur'an dan Terjemahnya. Arab Saudi: Wakaf Dari Pelayanan Dua Tanah Suci, 1418H.
Manzuūr, Ibn. Lisān al-'Arab. Mesir: Dār alMa'ārif, 1991.

Shauq Daif, Täikh al-'Adab al-'Arab; al'Ashr al-Jahi, Cet. 2. tp: Dār al-Ma'ārif, 1965.

Umar, Mustofa .Konsep Kufur dalam alQur'an dan poyeksinya terhadap teks hadis dalam Jurnal al-Risalah volume 12 no.1. mei: 2012.

Yunus, Mahmud. Arab Indonesia. Jakarta: Mahmud Yunus Wa Dzurriyah, 1989.

Zakaryā, Abi Husain Aḥmad ibn Fāris ibn . Mu 'jam Maqāyis al-Lughah . Mesir: Dār al-Kutb 'Alamiyah, t.t. 